Published in final edited form as:

Environ Sci Technol. 2020 April 07; 54(7): 3979-3987. doi:10.1021/acs.est.9b06063.

\title{
Effect of Bicarbonate, Calcium, and pH on the Reactivity of As(V) and $\mathrm{U}(\mathrm{VI})$ Mixtures
}

\author{
Jorge Gonzalez-Estrella, \\ Department of Civil, Construction and Environmental Engineering and Center for Water and the \\ Environment, University of New Mexico, Albuquerque, New Mexico 87131, United States \\ Isabel Meza, \\ Department of Civil, Construction and Environmental Engineering, University of New Mexico, \\ Albuquerque, New Mexico 87131, United States
}

\section{Annie Jane Burns,}

Department of Earth and Planetary Sciences, University of New Mexico, Albuquerque, New Mexico 87131, United States

Abdul-Mehdi S. Ali,

Department of Chemical and Biological Engineering, University of New Mexico, Albuquerque, New Mexico 87131, United States

\section{Juan S. Lezama-Pacheco,}

Department of Environmental Earth System Science, Stanford University, Stanford, CA 94305, United States

Peter Lichtner,

Center for Water and the Environment, University of New Mexico, Albuquerque, New Mexico 87131, United States

\section{Nabil Shaikh,}

Department of Civil, Construction and Environmental Engineering, University of New Mexico, Albuquerque, New Mexico 87131, United States

\section{Scott Fendorf,}

Department of Environmental Earth System Science, Stanford University, Stanford, CA 94305, United States

José M. Cerrato

Department of Civil, Construction and Environmental Engineering and Center for Water and the Environment, University of New Mexico, Albuquerque, New Mexico 87131, United States

\section{Abstract}

Corresponding Author Phone: (001) (505) 277-0870; jorgegonzalez@unm.edu; Fax: (001) (505) 277-1918.

Supporting Information

The Supporting Information is available free of charge at https://pubs.acs.org/doi/10.1021/acs.est.9b06063.

Additional information regarding final $\mathrm{pH}$ of the batch aqueous chemistry experiments, solid analyses methods and results, and speciation calculations is available in Supporting Information. (PDF)

The authors declare no competing financial interest. 
Natural or anthropogenic processes can increase the concentration of uranium (U) and arsenic (As) above the maximum contaminant levels in water sources. Bicarbonate and calcium (Ca) can have major impacts on $\mathrm{U}$ speciation and can affect the reactivity between $\mathrm{U}$ and As. We therefore investigated the reactivity of aqueous $\mathrm{U}$ and As mixtures with bicarbonate and $\mathrm{Ca}$ for acidic and neutral $\mathrm{pH}$ conditions. In experiments performed with $1 \mathrm{mM} \mathrm{U}$ and As mixtures, $10 \mathrm{mM} \mathrm{Ca}$, and without added bicarbonate $\left(\mathrm{pCO}_{2}=3.5\right)$, aqueous $\mathrm{U}$ decreased to $<0.25 \mathrm{mM}$ at $\mathrm{pH} 3$ and 7 . Aqueous As decreased the most at $\mathrm{pH} 3(\sim 0.125 \mathrm{mM})$. Experiments initiated with $0.005 \mathrm{mM}$ As and $\mathrm{U}$ showed similar trends. X-ray spectroscopy (i.e., XAS and EDX) and diffraction indicated that U-As-Ca- and U-Ca-bearing solids resemble uranospinite $\left[\mathrm{Ca}\left(\mathrm{UO}_{2}\right)_{2}\left(\mathrm{AsO}_{4}\right)_{2} \cdot 10 \mathrm{H}_{2} \mathrm{O}\right]$ and becquerelite $\left[\mathrm{Ca}\left(\mathrm{UO}_{2}\right)_{6} \mathrm{O}_{4}(\mathrm{OH})_{6} \cdot 8\left(\mathrm{H}_{2} \mathrm{O}\right)\right]$. These findings suggest that U-As-Ca-bearing solids formed in mixed solutions are stable at $\mathrm{pH}$ 3. However, the dissolution of U-As-Ca and U-Cabearing solids at $\mathrm{pH} 7$ was observed in reactors containing $10 \mathrm{mM}$ bicarbonate and $\mathrm{Ca}$, suggesting a kinetic reaction of aqueous uranyl-calcium-carbonate complexation. Our study provides new insights regarding $\mathrm{U}$ and As mobilization for risk assessment and remediation strategies.

\section{Graphical Abstract}

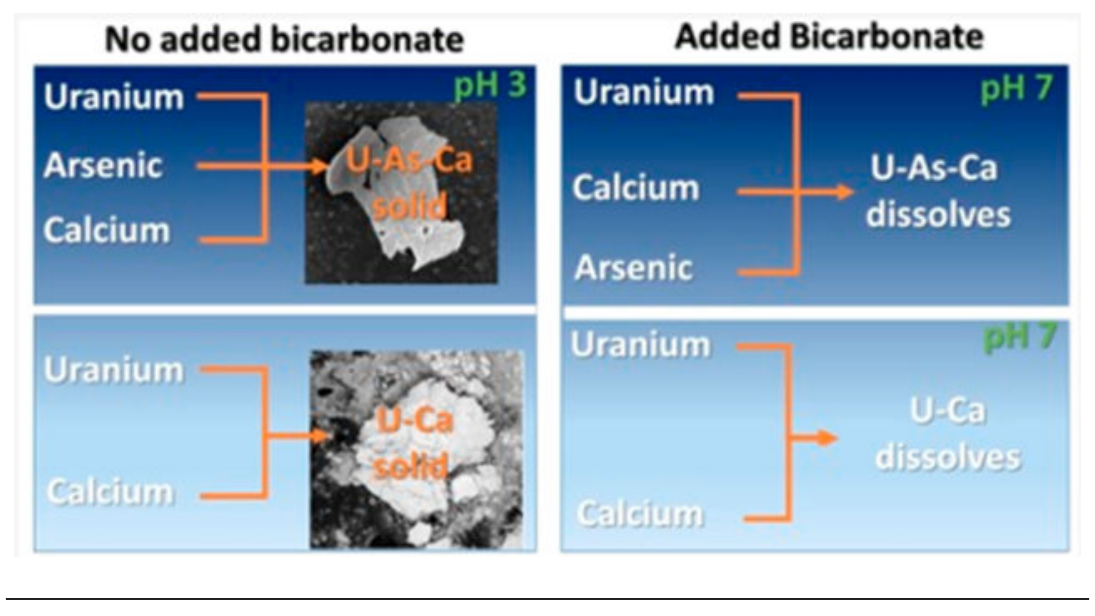

\section{INTRODUCTION}

Natural processes and anthropogenic activities such as mining and management of nuclear wastes can contaminate water sources. Previous studies have found uranium (U(VI)) and arsenic $(\mathrm{As}(\mathrm{V}))$ exceeding the USEPA maximum contaminant levels in water sources nearby abandoned mine waste located in Native American communities. ${ }^{1,2}$ The concentration of $\mathrm{U}(\mathrm{VI}), \mathrm{As}(\mathrm{V})$, and other metals can range from $\mu \mathrm{g} \mathrm{\textrm {L } ^ { - 1 }}$ to thousands of $\mathrm{mg} \mathrm{L}^{-1}$ at mine waste, ${ }^{1-3}$ in situ leaching,,${ }^{4,5}$ mill tailings,,${ }^{6,7}$ roll front deposits,${ }^{8}$ and post restoration sites. Aside from industrial activities, groundwater sources that supply more than 100 million inhabitants contain As concentrations higher than $0.01 \mathrm{mg} \mathrm{L}^{-1} .9$ Several countries deal with high concentrations of As in their water sources. ${ }^{10,11}$ Uranium and As at these concentrations pose potential health hazards for communities located near abandoned mine sites or near water sources with high geogenic concentrations. ${ }^{12}$

The mobility of both $\mathrm{U}$ and As in water depends on redox conditions, $\mathrm{pH}$, organic and inorganic ligands such as carbonate or phosphate, iron $(\mathrm{Fe}), \mathrm{Ca}$, and a variety of complex 
biogeochemical processes. ${ }^{13}$ Oxidation of U(IV) through natural weathering or anthropogenic processes can generate $\mathrm{U}(\mathrm{VI})$-bearing minerals such as schoepite $\left(\mathrm{UO}_{2}\right)_{8} \mathrm{O}_{2}(\mathrm{OH})_{12} \cdot 12\left(\mathrm{H}_{2} \mathrm{O}\right)$, becquerelite $\left[\mathrm{Ca}-\left(\mathrm{UO}_{2}\right)_{6} \mathrm{O}_{4}(\mathrm{OH})_{6} \cdot 8\left(\mathrm{H}_{2} \mathrm{O}\right)\right]$, liebigite $\left[\mathrm{Ca}_{2} \mathrm{UO}_{2}\left(\mathrm{CO}_{3}\right)_{3} \cdot 11 \mathrm{H}_{2} \mathrm{O}\right]$, or autunite $\left[\mathrm{Ca}\left(\mathrm{UO}_{2}\right)_{2}\left(\mathrm{PO}_{4}\right)_{2} \cdot 11 \mathrm{H}_{2} \mathrm{O}\right] \cdot{ }^{14-16}$ Oxidation of arsenopyrite transforms As to $\mathrm{As}(\mathrm{III})$ and $\mathrm{As}(\mathrm{V})$ and $\mathrm{Fe}$ to $\mathrm{Fe}(\mathrm{III})$, producing a variety of secondary minerals such as As coprecipitated with jarosite $\left[\mathrm{KFe}^{\mathrm{III}}{ }_{3}(\mathrm{OH})_{6}\left(\mathrm{SO}_{4}\right)_{2}\right]$ and other $\mathrm{Fe}(\mathrm{III})$ oxides (e.g., ferrihydrite $\left[\mathrm{Fe}_{2} \mathrm{O}_{3} \cdot 0.5 \mathrm{H}_{2} \mathrm{O}\right]$, goethite $[a-\mathrm{FeO}(\mathrm{OH})]$, hematite $\left[\mathrm{Fe}_{2} \mathrm{O}_{3}\right]$ ), which have a high binding affinity for $\mathrm{As}(\mathrm{V})$ at $\mathrm{pH}<8.5 .{ }^{17}$ Uranium(VI) and $\mathrm{As}(\mathrm{V})$ are the predominant oxidation states for redox conditions characteristic of surface oxidizing environments. Sorption and oxidative dissolution processes of these secondary minerals can release $\mathrm{U}$ and As into water.

Under oxidizing conditions, $\mathrm{U}$ in the aqueous phase generally occurs as the uranyl ion $\left(\mathrm{UO}_{2}{ }^{2+}\right)$ while As occurs as the pentavalent arsenate $\left(\mathrm{AsO}_{4}{ }^{3-}\right)$ oxyanion. Uranyl can complex with other ligands such as carbonate or phosphate. The formation of ternary U-Ca$\mathrm{CO}_{3}$ aqueous complexes facilitates the mobility of $\mathrm{U}$ at $\mathrm{pH}$ values higher than $6^{18-21}$ whereas uranyl and phosphate $\left(\mathrm{PO}_{4}{ }^{3-}\right)$ form a stable insoluble complex over a wide $\mathrm{pH}$ range. ${ }^{22}$ Arsenate remains negatively charged within a wide $\mathrm{pH}$ range given that arsenic acid has similar acidity constants as phosphoric acid. ${ }^{23}$ Arsenic and phosphorus have similar atomic radii, the same number of valence electrons, and nearly identical electronegativity and orbital configurations. ${ }^{24,25}$ The similarities of phosphate $\left(\mathrm{PO}_{4}{ }^{3-}\right)$ and arsenate $\left(\mathrm{AsO}_{4}{ }^{3-}\right)$ ions can potentially affect the mobility of both $\mathrm{U}$ and As in natural waters.

Simultaneous occurrence of $\mathrm{U}$ and As in $\mathrm{U}$ ores can lead to the contamination of water bodies. ${ }^{6}$ Uranium and As have been found in surface waters, mine waste, and background soil. ${ }^{2,3}$ Uranium and As can form various uranyl-arsenate complexes depending mainly on the $\mathrm{pH}$ and $\mathrm{U}$ and As concentrations. For 1:1 conditions, $\mathrm{UO}_{2}\left(\mathrm{H}_{2} \mathrm{AsO}_{4}\right)(\mathrm{H} 2 \mathrm{O})_{3}{ }^{+}$, $\mathrm{UO}_{2}\left(\mathrm{HAsO}_{4}\right)\left(\mathrm{H}_{2} \mathrm{O}\right)_{3}{ }^{0}, \mathrm{UO}_{2}\left(\mathrm{AsO}_{4}\right)\left(\mathrm{H}_{2} \mathrm{O}\right)_{3}{ }^{-}$are the dominant species. ${ }^{26}$ Uranyl-arsenate complexes deprotonate even at acidic $\mathrm{pH}$ increasing their capacity to react with iron $(\mathrm{Fe})$ and aluminum (Al) surfaces and to form other $\mathrm{U}$-As bearing minerals. Thus, the reactivity of $\mathrm{U}$ As complexes may be relevant for the formation of U-Ca, As-Ca, or U-As-Ca minerals in Ca-rich waters. ${ }^{6,13}$ Calcium is commonly accompanied by carbonate in minerals (e.g., calcite, aragonite, vaterite). ${ }^{27}$ Carbonate can limit the interaction between U, As, and Ca by forming highly stable and mobile $\mathrm{U}(\mathrm{VI})$ (hydroxy)-carbonate and calcium-uranyl-carbonate aqueous complexes. ${ }^{18,28}$ The reactions between $\mathrm{As}(\mathrm{V})$ and $\mathrm{Fe}(\mathrm{III})$, and $\mathrm{U}(\mathrm{VI})$ and phosphate and the stability of uranyl-arsenate mineral phases have been widely studied. ${ }^{13,15,29}$ However, the underlying mechanisms of the aqueous reactions affecting $\mathrm{U}(\mathrm{VI})$ and $\mathrm{As}(\mathrm{V})$ reactivity ${ }^{26}$ and the effect of $\mathrm{Ca}$ and carbonate on the mobility of $\mathrm{U}$-As complexes in water are still unresolved. ${ }^{26}$

The objective of this study is to determine the effect of $\mathrm{Ca}$, carbonate, and $\mathrm{pH}$ on the chemical reactivity of $\mathrm{As}(\mathrm{V})$ and $\mathrm{U}(\mathrm{VI})$ in oxic conditions by integrating batch experiments, aqueous chemistry, microscopy, and spectroscopy. Our study advances understanding regarding the role of $\mathrm{Ca}$ and carbonate in the precipitation and solubility of $\mathrm{U}(\mathrm{VI})$ and $\mathrm{As}(\mathrm{V})$ at $\mathrm{pH} 3$ and 7. The information obtained from this study will provide new insights concerning the effect of bicarbonate and $\mathrm{Ca}$ on the reactivity and mobility of $\mathrm{U}(\mathrm{VI})$ and 
$\operatorname{As}(\mathrm{V})$ in acidic and neutral waters which is relevant for transport and remediation applications. Hereafter, we will refer to $\mathrm{U}(\mathrm{VI})$ and $\mathrm{As}(\mathrm{V})$ as $\mathrm{U}$ and $\mathrm{As}$, respectively.

\section{MATERIALS AND METHODS}

\section{Reactants.}

$\mathrm{Na}_{2} \mathrm{HAsO}_{4} \cdot 7 \mathrm{H}_{2} \mathrm{O}$ (>98\% purity) was purchased from Sigma-Aldrich and $\mathrm{UO}_{2}\left(\mathrm{CH}_{3} \mathrm{COO}\right)_{2} \cdot 2 \mathrm{H}_{2} \mathrm{O}(98 \%), \mathrm{NaHCO}_{3}(>99.7 \%)$, and $\mathrm{CaCl}_{2}(>96 \%)$ were acquired from ACS chemicals.

\section{Aqueous Chemistry.}

Experiments were carried out to investigate the reactivity of soluble As, $\mathrm{U}, \mathrm{Ca}$, and bicarbonate at acidic $\mathrm{pH} 3$ and neutral $\mathrm{pH}$ 7. The high and low concentrations of $\mathrm{U}$ and As were selected to represent relevant conditions found at mine waste, ${ }^{1-3}$ in situ leaching, ${ }^{4,5}$ mill tailings, ${ }^{6,7}$ roll front deposits,${ }^{8}$ and post restoration sites. Experiments were supplied with stock solutions to reach an initial concentration of either 1 or $0.005 \mathrm{mM}$ of As and $\mathrm{U}$, $10 \mathrm{mM} \mathrm{Ca}$, and $10 \mathrm{mM}$ bicarbonate. Treatments without added bicarbonate were also included. Experiments with added bicarbonate were assumed as closed systems with the exception of a short period of time during the initial preparation and sampling, and experiments without added bicarbonate were assumed to be at equilibrium with atmospheric $\mathrm{CO}_{2}$. Individual $4 \mathrm{mM}$ stock solutions were prepared to provide a source of As and $\mathrm{U}$ ions using $\mathrm{Na}_{2} \mathrm{HAsO}_{4} \cdot 7 \mathrm{H}_{2} \mathrm{O}$ and $\mathrm{UO}_{2}\left(\mathrm{CH}_{3} \mathrm{COO}\right)_{2} \cdot 2 \mathrm{H}_{2} \mathrm{O}$, respectively. Another set of $20 \mathrm{mM}$ stock solutions was prepared to provide a source of $\mathrm{Ca}$ and bicarbonate ions using $\mathrm{CaCl}_{2}$ and $\mathrm{NaHCO}_{3}$, respectively. In order to reach the desired $\mathrm{pH}$, all stock solutions of $\mathrm{Na}_{2} \mathrm{HAsO}_{4} \cdot 7 \mathrm{H}_{2} \mathrm{O}, \mathrm{UO}_{2}\left(\mathrm{CH}_{3} \mathrm{COO}\right)_{2} \cdot 2 \mathrm{H}_{2} \mathrm{O}, \mathrm{NaHCO}_{3}, \mathrm{CaCl}_{2}$, and DI water (for dilution purposes) were independently adjusted dropwise to $\mathrm{pH} 3$ using $12.4 \mathrm{~N} \mathrm{HCl}$ and dropwise to pH 7 using $10 \mathrm{~N}$ as required before any mixing occurred. Subsequently, the solutions were mixed as required for each treatment (Table 1). The final $\mathrm{pH}$ was recorded to ensure that it remained in the desired value (Table S1). Once the appropriate mixtures were prepared, the vials were mixed at $60 \mathrm{rpm}$ in an analog rotisserie tube rotator (Scologex MX-RL-E, Rocky Hill, CT, US) and an initial $1 \mathrm{~mL}$ sample was taken from the supernatant. Next, $1 \mathrm{~mL}$ samples were taken from the supernatant at $0.25,0.5,1,2,4,24$, and $48 \mathrm{~h}$. These samples were filtered through $0.2 \mu \mathrm{m}$ syringe filter membranes (Pall Acrodisc, Westborough, MA, USA), acidified with high purity $\mathrm{HNO}_{3}$, and refrigerated at $4{ }^{\circ} \mathrm{C}$ for subsequent analysis. Soluble As, $\mathrm{U}$, and $\mathrm{Ca}$ concentrations were quantified by inductively coupled plasma optical emission spectroscopy (ICP-OES) and trace metal concentrations by inductively coupled plasma optical mass spectroscopy (ICP-MS). If precipitates formed, a sample of the solids was taken and then analyzed with scanning electron microscopy/emission diffraction spectroscopy (SEM/EDS), X-ray diffraction spectroscopy (XRD), and X-ray absorption spectroscopy (XAS). The $\mathrm{pH}$ of all vials was measured at the end of the experiment. (Note that the Na concentration was not evaluated.)

\section{Solid Analyses.}

Solid samples were analyzed using X-ray diffraction (XRD), scanning electron microscopy (SEM), X-ray fluorescence (XRF), X-ray photoelectron spectroscopy (XPS), and X-ray 
absorption spectroscopy (XAS). The details of these analyses are described in the

Supporting Information.

Inductively Coupled Plasma Analyses.

The soluble metal concentration was measured using a PerkinElmer Optima 5300DV ICPOES with a detection limit of $0.5 \mathrm{mg} \mathrm{L}^{-1}$. Trace elemental concentrations were measured with a PerkinElmer NexION 300D (Dynamic Reaction Cell) ICP-MS with a detection limit of $0.5 \mu \mathrm{g} \mathrm{L}{ }^{-1}$. Both ICPs were calibrated with a five-point calibration curve, and QA/QC measures were taken to ensure quality results.

\section{Speciation Calculations.}

Calculations were carried out using the open-source computer code PFLOTRAN that runs on MacOSX, linux, and Windows. ${ }^{30}$ Speciation calculations were based on chemical equilibrium modeling using inputs from experimental conditions used in this study as a tool to gain insight about aqueous complexation and solid saturation state. PFLOTRAN can perform speciation calculations with options to input total and free ion concentrations, mineral and gas equilibrium constraints, and charge balance. The extended Debye- Hückel algorithm is used to compute activity coefficients. The PFLOTRAN thermodynamic database was expanded to include equilibrium constants for becquerelite and liebigite taken from Gorman-Lewis et al. ${ }^{31}$ and for troegerite from Nipruk et al., ${ }^{32}$ and includes the most recent update to $\mathrm{U}$ complexes. ${ }^{18,19,33}$ The geochemical system was described with eight primary species $\left(\mathrm{UO}_{2}{ }^{2+}, \mathrm{AsO}_{4}{ }^{3-}, \mathrm{Ca}^{2+}, \mathrm{Na}^{+}, \mathrm{H}^{+}, \mathrm{CO}_{3}{ }^{2-}, \mathrm{Cl}^{-}\right.$, and acetate $\left.{ }^{-}\right)$. In the experiments without added bicarbonate, we assumed a partial pressure of $\mathrm{CO}_{2}$ in the atmosphere of $10^{-3.5}$ bar $\left(\mathrm{pCO}_{2}=3.5\right)$.

\section{RESULTS AND DISCUSSION}

\section{Aqueous Chemistry Experiments.}

Temporal variation on $\mathrm{U}$ and As concentrations depended on their mixtures, $\mathrm{pH}$, and addition of bicarbonate (Figures 1 and 2). The concentration of aqueous $U$ and As decreased the most in assays without added bicarbonate $\left(\mathrm{pCO}_{2}=3.5\right)$. In mixtures of $1 \mathrm{mM} \mathrm{U}$ and/or As, and $10 \mathrm{mM} \mathrm{Ca}$ performed at $\mathrm{pH} 3$ without added bicarbonate, both aqueous $\mathrm{U}$ and $\mathrm{As}$ decreased from 1 to $<0.25 \mathrm{mM}$ ( $>75 \%$ decrease) (Figure 1). In mixtures of U, As, and $\mathrm{Ca}$ performed at $\mathrm{pH} 7$, aqueous $\mathrm{U}$ rapidly decreased from $1 \mathrm{mM}$ and remained at $<0.0004 \mathrm{mM}$ ( $>99 \%$ decrease, Figure 1A), whereas aqueous As remained $\sim 0.9 \mathrm{mM}$ (Figure 1B). Uranium and As behaved differently when mixed compared to when they were not mixed (Figure 1C and 2D). Aqueous $\mathrm{U}$ and As remained close to $1 \mathrm{mM}$ the entire experiment at $\mathrm{pH} 3$ (Figure $1 \mathrm{C}$ and 2D). At $\mathrm{pH} 7$, aqueous $\mathrm{U}$ rapidly decreased from 1 to $\sim 0.019 \mathrm{mM}$ ( $\sim 80 \%$ decrease, Figure 1C) whereas As concentration remained $\sim 1 \mathrm{mM}$ (Figure 1D). Interestingly, the $\mathrm{U}$ concentration increased in mixed and nonmixed reactors containing $10 \mathrm{mM}$ bicarbonate and $\mathrm{Ca}$ at $\mathrm{pH} 7$, suggesting a kinetic reaction of $\mathrm{U}$ with bicarbonate and $\mathrm{Ca}$ (Figure $1 \mathrm{~A}$ and $1 \mathrm{C}$ ). In assays containing $\mathrm{Ca}$ and bicarbonate, the $\mathrm{U}$ concentration returned to its initial concentration of $1 \mathrm{mM}$ after $4 \mathrm{~h}$ (Figure 1C). Arsenic concentration remained $\sim 1 \mathrm{mM}$ in assays containing only As, Ca, and bicarbonate (Figure 1D). 
Analogous experiments were performed with an initial concentration of $0.005 \mathrm{mM} \mathrm{U}$ and/or As, $10 \mathrm{mM} \mathrm{Ca}$, with $10 \mathrm{mM}$ of bicarbonate or without added bicarbonate $\left(\mathrm{pCO}_{2}=3.5\right)$. Temporal variation in $\mathrm{U}$ and As concentrations depended on their mixtures, $\mathrm{pH}$, and addition of bicarbonate (Figure 2). In mixtures of $\mathrm{U}, \mathrm{As}$, and Ca performed at $\mathrm{pH} 3$ without added bicarbonate, both aqueous $U$ and As rapidly decreased from 0.005 to $~ 0.0022$ ( $55 \%$ decrease; Figure 2). In mixtures of $\mathrm{U}$, As, and Ca performed at $\mathrm{pH} 7$, aqueous $\mathrm{U}$ decreased from 0.005 to as low as 0.0013 ( $74 \%$ decrease, Figure 1A) and aqueous As decreased from 0.005 to as low as $0.0025 \mathrm{mM}$ ( $50 \%$ decrease, Figure $2 \mathrm{~B})$. Uranium and As behaved differently when they were not mixed (Figure $2 \mathrm{C}$ and $2 \mathrm{D}$ ). At $\mathrm{pH} 3$, the concentration of $\mathrm{U}$ and As remained close to the initial concentration (Figure 2C and 2D), whereas at $\mathrm{pH} 7$ the aqueous $\mathrm{U}$ decreased from 0.005 to $\sim 0.002$ ( $\sim 60 \%$ decrease, Figure $2 \mathrm{C}$ ). For experiments with an initial concentration of $0.005 \mathrm{mM}$ (Figure 2C), the $\mathrm{U}$ concentration did not noticeably increase after reacting with added bicarbonate and supplied with $\mathrm{Ca}$ at $\mathrm{pH} 7$ as observed in experiments using initial concentrations of $1 \mathrm{mM}$ (Figure $1 \mathrm{C}$ ). In mixtures of $\mathrm{U}$, As, $\mathrm{Ca}$, and bicarbonate, the $\mathrm{U}$ concentration increased from 0.0015 to $0.0025 \mathrm{mM}$ (Figure $2 \mathrm{~A}$ ) while the As concentration remained $>0.003 \mathrm{mM}$. In assays with added bicarbonate and supplied with $\mathrm{U}$ and $\mathrm{Ca}$, the aqueous $\mathrm{U}$ concentration increased over time to its initial value (Figure 2C).

\section{Solid Phase Analyses.}

Precipitates recovered from the experiments initiated with $1 \mathrm{mM}$ of $\mathrm{U}$ and/or As contained mixtures of $\mathrm{U}, \mathrm{As}$, and $\mathrm{Ca}$ according to the EDS and SEM analyses (Figure 3). The solid that precipitated at $\mathrm{pH} 3$ contained $\mathrm{U}$, As, and $\mathrm{Ca}$ (Figure 3A), while the solid that precipitated at $\mathrm{pH} 7$ contained primarily $\mathrm{U}$ (Figure 3B). The formation of these precipitates explains the decrease in the aqueous concentration of $U$ and As. Due to a limited amount of solid sample, SEM and EDS analyses were used as an initial analysis of the solid phases. Additional XRD analyses identified a similar pattern to that of meta-zeunerite $\left[\mathrm{Cu}\left(\mathrm{UO}_{2}\right)_{2}\left(\mathrm{AsO}_{4}\right)_{2} \cdot 8 \mathrm{H}_{2} \mathrm{O}\right.$ ] for the solid precipitated at $\mathrm{pH} 3$ (Figure $\mathrm{S} 1 \mathrm{~A}$ ). However, the $\mathrm{XRD}$ pattern of the solid at $\mathrm{pH} 7$ seems to have a mixture of solids with similar chemical structure to becquerelite $\left[\mathrm{Ca}\left(\mathrm{UO}_{2}\right)_{6} \mathrm{O}_{4}(\mathrm{OH})_{6} \cdot 8\left(\mathrm{H}_{2} \mathrm{O}\right)\right]$ and meta-zeunerite (Figure S1 B). Given that our experimental system did not include $\mathrm{Cu}$, it is likely that $\mathrm{Ca}$ is part of the structure of the uranyl arsenate mineral to form a solid such as uranospinite $\left[\mathrm{Ca}\left(\mathrm{UO}_{2}\right)_{2}\left(\mathrm{AsO}_{4}\right)_{2} \cdot 10 \mathrm{H}_{2} \mathrm{O}\right]$ with similar chemical structure to that of meta-zeunerite.

Results from $\mathrm{U}_{\mathrm{III}}$-Edge EXAFS shell-by-shell fits confirm that a solid with similar chemical structure to uranospinite is the main solid phase formed in mixed $\mathrm{U}$ and As experiments at $\mathrm{pH} 3$ (Figure 4, Table S2). For experiments having only $\mathrm{U}$ or As at $\mathrm{pH} 7, \mathrm{U}$ $\mathrm{L}_{\mathrm{III}}$-Edge EXAFS shell-by-shell fits indicate that becquerelite is the main solid phase formed (Figure 4, Table S2). These results are confirmed by X-ray diffraction analyses which identify minerals resembling meta-zeunerite (or uranospinite given that our experiments have no $\mathrm{Cu}$ ) and becquerelite (Figure $\mathrm{S} 1$ ). Note that the structure of uranospinite has not been yet resolved for several decades. ${ }^{34}$ Thus, the XRD data for uranospinite are not available in the ICSD database. Instead, meta-zeunerite was used in its place as a surrogate. Linear combination fits for $\mathrm{U} \mathrm{L}_{\mathrm{III}}$-Edge EXAFS for reacted solids obtained from mixed $\mathrm{U}$ and As experiments at $\mathrm{pH} 7$ suggest that a mixture of $82.0 \%$ 
uranospinite and $18.0 \%$ becquerelite was formed (Figure 4). The linear combination fits to Ca K-edge spectra yielded a mixture of $71.6 \%$ uranospinite and $28.4 \%$ becquerelite. The linear combination results for Ca K-Edge EXAFS spectra are within $10 \%$ error for the linear combination fits reported for $\mathrm{U} \mathrm{L}_{\mathrm{III}}$-Edge EXAFS spectra. These results highlight the relevance of precipitation and dissolution of U-, As-, and Ca-bearing solids under the conditions investigated in this study.

\section{Solubility Considerations.}

Precipitation of Uranyl-Arsenate-Calcium Bearing Solids.-Aqueous $\mathrm{U}$ and As decreased in mixtures with $\mathrm{Ca}$ and without added bicarbonate $\left(\mathrm{pCO}_{2}=3.5\right)$ at $\mathrm{pH} 3$ and 7 and aqueous As partially decreased at $\mathrm{pH} 7$ due to precipitation of a U-As-Ca-bearing solid similar to uranospinite. Uranospinite is a hydrated arsenate of $\mathrm{Ca}$ and $\mathrm{U}$ that usually occurs with other secondary uranium minerals such as zeunerite $\left[\mathrm{Cu}\left(\mathrm{UO}_{2}\right)_{2}\left(\mathrm{AsO}_{4}\right)_{2} \cdot \mathrm{H}_{2} \mathrm{O}\right]$, walpurgite $\left[(\mathrm{BiO})_{4}\left(\mathrm{UO}_{2}\right)\left(\mathrm{AsO}_{4}\right)_{2} \cdot 2 \mathrm{H}_{2} \mathrm{O}\right]$, and troegerite $\left[\left(\mathrm{H}_{3} \mathrm{O}\right)\left(\mathrm{UO}_{2}\right)\left(\mathrm{AsO}_{4}\right) \cdot 3 \mathrm{H}_{2} \mathrm{O}\right]$. Uranospinite occurs in small amounts in calcite rocks as a thin pale yellow to white coating associated with calcite. ${ }^{35}$ Uranospinite has also been found in $\mathrm{U}$ ores ${ }^{36,37}$ and in river beds ${ }^{35}$ that also contain As. Other minerals such as meta-zeunerite also occur in $\mathrm{U}$ ores rich in As and other metals. ${ }^{38}$ The formation of U-As precipitates can lead to the sequestration of the aqueous forms of both metals and other cations. ${ }^{24,38}$ Early work investigating the synthesis of uranospinite obtained a flocculent lemon-yellow precipitate utilizing calcium chloride, uranyl nitrate, and monohydrogen sodium arsenate in molar ratio of 1:2:2 at room temperature. ${ }^{39}$ Such conditions are similar to those employed in our experiment. Therefore, our results suggest that the conditions applied in our experiments likely facilitated the formation of U-As-Ca-bearing precipitates.

Understanding the reactivity between $\mathrm{U}$ and As is relevant due to the large number of environments where both $U$ and As simultaneously occur across the world. ${ }^{6,7,12,38}$ Previous research investigating the reactivity of $\mathrm{U}$ and As has suggested that a fraction of the $\mathrm{U}$-As complexes deprotonate throughout an acid $\mathrm{pH}$ range. ${ }^{26}$ Complexed U-As species such as $\mathrm{UO}_{2} \mathrm{H}_{2} \mathrm{AsO}_{4}\left(\mathrm{H}_{2} \mathrm{O}\right)_{3}{ }^{+}$and $\mathrm{UO}_{2}\left(\mathrm{H}_{2} \mathrm{AsO}_{4}\right)_{2}\left(\mathrm{H}_{2} \mathrm{O}\right)^{0}$ dominate in an acidic $\mathrm{pH}$ range, while $\mathrm{UO}_{2}\left(\mathrm{HAsO}_{4}\right)\left(\mathrm{H}_{2} \mathrm{AsO}_{4}\right)\left(\mathrm{H}_{2} \mathrm{O}\right)^{-}$species dominate from $\mathrm{pH}$ 7.2 to 10.7. ${ }^{26}$ These U-As species enable the sorption of $\mathrm{U}$ onto $\mathrm{Al}$ and $\mathrm{Fe}$ oxy(hydroxides) ${ }^{26}$ suggesting that an analogue behavior can occur with $\mathrm{Ca}$ oxy(hydroxides) as well. The affinity between $\mathrm{U}, \mathrm{As}$, and $\mathrm{Ca}$ is not surprising as arsenates are usually considered an analogue of phosphate minerals with similar sizes and charges in their ionic units. ${ }^{24}$ Phosphates are well-known for forming precipitates of limited solubility with $\mathrm{U}$ and $\mathrm{Ca}$ such as autunite $\left(\mathrm{Ca}\left[\left(\mathrm{UO}_{2}\right)\left(\mathrm{PO}_{4}\right)\right]_{2} \cdot 11 \mathrm{H}_{2} \mathrm{O}\right)$. 40,41

Precipitation of Uranyl-Calcium Solids.-Experiments showed that the concentration of $\mathrm{U}$ decreased in the experiments without added bicarbonate $\left(\mathrm{pCO}_{2}=3.5\right)$ and supplied either with only $\mathrm{U}$ and $\mathrm{Ca}$ or with a mixture of $\mathrm{U}$, As, and $\mathrm{Ca}$ due to the precipitation of the uranyl-calcium solid resembling becquerelite. Becquerelite $\left(\mathrm{Ca}\left(\mathrm{UO}_{2}\right)_{6} \mathrm{O}_{4}(\mathrm{OH})_{6} \cdot 8 \mathrm{H}_{2} \mathrm{O}\right)$, a hydrated uranyl oxyhydroxide mineral phase, is one of the most commonly occurring secondary uranyl carbonate minerals. ${ }^{42}$ Hydrated uranyl oxyhydroxide phases mainly form in uranium rich aqueous solutions and develop early on during the oxidation and corrosion 
of uraninite-bearing ores. ${ }^{43,44}$ Becquerelite and other minerals such liebigite $\left(\mathrm{Ca}_{2} \mathrm{UO}_{2}\left(\mathrm{CO}_{3}\right)_{3} \cdot 11 \mathrm{H}_{2} \mathrm{O}\right)$, K-compreignacite $\left(\mathrm{K}_{2}\left(\mathrm{UO}_{2}\right)_{6} \mathrm{O}_{4}(\mathrm{OH})_{6} \cdot 8\left(\mathrm{H}_{2} \mathrm{O}\right)\right)$, and Nacompreignacite $\left(\mathrm{Na}_{2}\left(\mathrm{UO}_{2}\right)_{6} \mathrm{O}_{4}(\mathrm{OH})_{6} \cdot 8\left(\mathrm{H}_{2} \mathrm{O}\right)\right)$ are commonly present in uranium ores with oxidizing conditions and abundance of $\mathrm{Ca}, \mathrm{K}$, or $\mathrm{Na}^{31,45}$

According to the speciation calculations, becquerelite is oversaturated (saturation index $=$ 0.56) at $\mathrm{pH} 7$ (Table $\mathrm{S} 3$ ). A recent study suggested that $\mathrm{U}$ can form precipitates with $\mathrm{Ca}$ and hydroxyl for $\mathrm{pH}$ values $>5$, consistent with our results in absence of bicarbonate or other complexing agents. ${ }^{46}$ Research has also suggested that formation of synthetic becquerelite can take place in a circumneutral $\mathrm{pH}$ range. ${ }^{47}$ Previous work included synthesis of becquerelite by the addition of stoichiometric quantities of uranyl and calcium nitrate at room temperature, basic $\mathrm{pH}$, and oxidizing conditions or by oxidizing schoepite. ${ }^{44}$ Our findings suggest that the conditions applied in our experiments facilitated the formation of U-Ca precipitates.

Effect of Bicarbonate on Precipitate Solubility.-Bicarbonate facilitated the dissolution of U-As-Ca and U-Ca precipitates (Figures 1A,B,D and 2B,C). Our results suggest that solids that initially precipitated, decreasing the $\mathrm{U}$ and As concentration, completely or partially redissolved over time in contact with bicarbonate. Other studies have also observed this phenomenon with $\mathrm{U}$ but did not focus the redissolution of $\mathrm{U}$ precipitates due to the reaction with bicarbonate. ${ }^{47,48}$ Initially, the dissolved $U$ and As concentrations were low leading to low solubility of U-bearing minerals and hence highly super-saturated conditions. As the $\mathrm{U}$ reacted over time in both mixed (Figure 1A) and nonmixed systems (Figure 1C), the concentration of uranyl-carbonate complexes increased, and the minerals dissolved until almost complete dissolution took place.

Speciation calculations using experimental conditions for this study at $\mathrm{pH} 7$ with $1 \mathrm{mM}$ mixtures of $\mathrm{U}$ and $\mathrm{As}$ and $10 \mathrm{mM}$ of $\mathrm{Ca}$ and bicarbonate suggest that the main $\mathrm{U}$ aqueous complexes were $\mathrm{Ca}_{2} \mathrm{UO}_{2}\left(\mathrm{CO}_{3}\right)(74.4 \%)$ and $\mathrm{CaUO}_{2}\left(\mathrm{CO}_{3}\right)_{3}{ }^{2-}(14.4 \%)$. The main As complexes were $\mathrm{HAsO}_{4}{ }^{2-}(88.9 \%)$ and $\mathrm{H}_{2} \mathrm{AsO}_{4}{ }^{-}(11.1 \%)$ for the experiments supplied with $\mathrm{U}$ and As (Table S4). Simulations of the experiments supplied with $\mathrm{U}$ and As $1 \mathrm{mM}$ mixtures, $10 \mathrm{mM}$ of $\mathrm{Ca}$, and without added bicarbonate $\left(\mathrm{pCO}_{2}=3.5\right)$ at $\mathrm{pH} 7$ suggest that the main $\mathrm{U}$ complex was $\mathrm{UO}_{2} \mathrm{HAsO}_{4}(97.7 \%)$ while the dominant As complexes were $\mathrm{HAsO}_{4}{ }^{2-}(52.9 \%)$ and $\mathrm{H}_{2} \mathrm{AsO}_{4}{ }^{-}$(47.1\%) (Table S5). In the experiments supplied with 1 $\mathrm{mM}$ of $\mathrm{U}$ and $10 \mathrm{mM}$ of $\mathrm{Ca}$ and bicarbonate, simulations indicated that the main species were $\mathrm{Ca}_{2} \mathrm{UO}_{2}\left(\mathrm{CO}_{3}\right)_{3}(79.9 \%), \mathrm{CaUO}_{2}\left(\mathrm{CO}_{3}\right)_{3}{ }^{2-}(12.8 \%)$, and $\mathrm{UO}_{2}\left(\mathrm{CO}_{3}\right)_{3}{ }^{4-}(8 \%)$ (Table S4), while the main complexes without added bicarbonate $\left(\mathrm{pCO}_{2}=3.5\right)$ were $\left(\mathrm{UO}_{2}\right)_{2} \mathrm{CO}_{3}(\mathrm{OH})_{3}{ }^{-}$ $(62.3 \%)$ and $\left(\mathrm{UO}_{2}\right)_{3}(\mathrm{OH})_{5}{ }^{+}(26.7 \%)$ indicating the role of bicarbonate complexing with $\mathrm{U}$ and $\mathrm{Ca}$ (Table S4).

Previous studies have indicated that carbonates facilitate the formation of aqueous uranylcarbonato complexes ${ }^{18-20,31,49-51}$ in agreement with our findings. Aqueous uranyl carbonato complexes alter $\mathrm{U}$ sorption at circumneutral $\mathrm{pH}$ and high partial $\mathrm{CO}_{2}$ pressures, ${ }^{47}$ and limit retention particularly when $\mathrm{Ca}$ is present. ${ }^{49}$ The distribution of uranyl-calcium-carbonato complexes depends on the specific aqueous geochemical conditions such as concentrations of alkaline earth metals, $\mathrm{pH}, \mathrm{pCO}_{2}, \mathrm{U}$ concentration, inorganic and organic ligands, and 
ionic strength. ${ }^{18}$ In our experiments, the reaction of solids with bicarbonate solubilized either partially or completely $U$ over time (Figure 1A,C) as evidenced by the increase in the $\mathrm{U}$ concentration with time. The synthetic nature of the precipitates may have facilitated their dissolution since research suggests that synthetic becquerelite is more soluble than natural becquerelite. ${ }^{44}$

The effect of bicarbonate on metal solubility is well-known. Carbonates are typically used to extract metals from soils and sediments including $\mathrm{U}$ and As. ${ }^{52-55}$ For instance, $1 \mathrm{M}$ sodium bicarbonate extracted $\approx 97 \%$ of $U$ from a contaminated soil. ${ }^{52}$ A concentration of $0.5 \mathrm{M}$ sodium bicarbonate leached up to $90 \%$ of $\mathrm{U}$ in flow-through column experiments. ${ }^{53}$ Sodium carbonate and sodium bicarbonate leached from $\approx 6.5$ up to $\approx 27$ more As compared to barium and manganese carbonate salts. ${ }^{54}$ These previous results suggest that the $10 \mathrm{mM}$ of sodium bicarbonate added to the system complexed $\mathrm{U}$ and As. This assumption was supported by our modeling results.

More information is necessary to better understand the mechanisms affecting the solubility of uranyl arsenate solids in environmentally relevant systems. Other work has observed the increase of aqueous $\mathrm{U}$ over time caused by the formation of $\mathrm{U}-\mathrm{Ca}-\mathrm{CO}_{3}$ complexes. ${ }^{56}$

Additional research is necessary to identify specific equilibrium constants and kinetic constraints of the role $\mathrm{U}-\mathrm{Ca}-\mathrm{CO}_{3}$ complexes in the dissolution of $\mathrm{U}-\mathrm{Ca}$ and $\mathrm{U}$-As bearing solids.

Environmental Implications.-Our findings indicate that $\mathrm{U}$, As, and $\mathrm{Ca}$ can react to form U-As-Ca precipitates at $\mathrm{pH} 3$ and a combination of U-Ca and U-As-Ca precipitates at $\mathrm{pH}$ 7. XAS and XRD analyses suggest that the precipitates resemble uranospinite and becquerelite. These results are in agreement with research indicating that As sequestered $\mathrm{U}$ leading to the formation of an immobile U-As mineral phase. ${ }^{38}$ Bicarbonate facilitates the dissolution of U-, As-, and Ca-bearing solids. These results agree with previous studies which found that bicarbonate and $\mathrm{Ca}$ facilitated the mobilization of uranium and arsenic in the aqueous phase. ${ }^{18,50,54,57}$ Future studies are needed to explore the role of kinetics in the formation of uranyl-carbonate complexes that can affect mineral solubility at alkaline $\mathrm{pH}$.

We recognize that these results are derived from data obtained from batch experiments performed under controlled laboratory conditions. Thus, the conditions investigated are simplifications of the natural environment found in mine waste, in situ leaching, mill tailings, roll front deposits, and post restoration sites. More research is necessary to investigate more complex mixtures of metals, $\mathrm{pH}$ range, and variability of oxic and anoxic conditions. Nonetheless, our research provides new insights about potential reactions occurring between $\mathrm{U}$ and $\mathrm{As}$ and the role of bicarbonate and $\mathrm{Ca}$ in their mobilization.

In mine tailing management facilities, mine waste, or natural systems where $\mathrm{U}$ and $\mathrm{As}$ simultaneously occur, ${ }^{1,6,58}$ the reactivity between $U$ and As can lead to the formation of precipitates, such as uranospinite, decreasing the mobilization of $U$ and As. However, in mine facilities, if the leachate remains untreated and reaches alkaline water bodies, $\mathrm{U}$ and As will likely be mobilized into the aqueous phase. Our results also suggest that $U$ and As can be removed in remediation of systems that already deal with acidic waste, and cations such 
as Ca may facilitate the precipitation of U-As-bearing minerals. As a whole, our study provides insights about $\mathrm{U}$ and As mobilization and information for possible remediation approaches.

\section{Supplementary Material}

Refer to Web version on PubMed Central for supplementary material.

\section{ACKNOWLEDGMENTS}

Research reported in this publication was supported by the National Institute of Environmental Health Sciences of the National Institutes of Health under Award Number P42ES025589. The content is solely the responsibility of the authors and does not necessarily represent the official views of the National Institutes of Health. Use of the Stanford Synchrotron Radiation Lightsource, SLAC National Accelerator Laboratory, is supported by the U.S. Department of Energy, Office of Science, Office of Basic Energy Sciences under Contract No. DE-AC02-76SF00515.

\section{REFERENCES}

(1). Blake JM; Avasarala S; Artyushkova K; Ali A-MS; Brearley AJ; Shuey C; Robinson WP; Nez C; Bill S; Lewis J; Hirani C; Pacheco JSL; Cerrato JM Elevated Concentrations of U and Cooccurring Metals in Abandoned Mine Wastes in a Northeastern Arizona Native American Community. Environ. Sci. Technol 2015, 49 (14), 8506-8514. [PubMed: 26158204]

(2). Blake JM; De Vore CL; Avasarala S; Ali AM; Roldan C; Bowers F; Spilde MN; Artyushkova K; Kirk MF; Peterson E; Rodriguez-Freire L; Cerrato JM Uranium mobility and accumulation along the Rio Paguate, Jackpile Mine in Laguna Pueblo, NM. Environ. Sci-Proc. Imp 2017, 19 (4), 605-621.

(3). Blake JM; Avasarala S; Ali A-MS; Spilde M; Lezama-Pacheco JS; Latta D; Artyushkova K; Ilgen AG; Shuey C; Nez C; Cerrato JM Reactivity of As and U co-occurring in Mine Wastes in northeastern Arizona. Chem. Geol 2019, 522, 26-37. [PubMed: 31371834]

(4). Saunders JA; Pivetz BE; Voorhies N; Wilkin RT Potential aquifer vulnerability in regions downgradient from uranium in situ recovery (ISR) sites. J. Environ. Manage 2016, 183, 67-83. [PubMed: 27576149]

(5). Ruiz O; Thomson BM; Cerrato JM Investigation of in situ leach (ISL) mining of uranium in New Mexico and post-mining reclamation. New Mex. Geol 2016, 38 (4), 77-85.

(6). Donahue R; Hendry MJ Geochemistry of arsenic in uranium mine mill tailings, Saskatchewan, Canada. Appl. Geochem 2003, 18 (11), 1733-1750.

(7). Robertson J; Hendry MJ; Kotzer T; Hughes KA Geochemistry of uranium mill tailings in the Athabasca Basin, Saskatchewan, Canada: A review. Crit. Rev. Environ. Sci. Technol 2019, 49, 157.

(8). Bullock LA; Parnell J Selenium and molybdenum enrichment in uranium roll-front deposits of Wyoming and Colorado, USA. J. Geochem. Explor 2017, 180, 101-112.

(9). Mukherjee A; Gupta S; Coomar P; Fryar AE; Guillot S; Verma S; Bhattacharya P; Bundschuh J; Charlet L Plate tectonics influence on geogenic arsenic cycling: From primary sources to global groundwater enrichment. Sci. Total Environ 2019, 683, 793-807. [PubMed: 31153003]

(10). He J; Charlet L A review of arsenic presence in China drinking water. J. Hydrol 2013, 492, 7988.

(11). Bundschuh J; Litter MI; Parvez F; Roman-Ross G; Nicolli HB; Jean JS; Liu CW; Lopez D; Armienta MA; Guilherme LRG; Cuevas AG; Cornejo L; Cumbal L; Toujaguez R One century of arsenic exposure in Latin America: A review of history and occurrence from 14 countries. Sci. Total Environ 2012, 429, 2-35. [PubMed: 21959248]

(12). Hoover J; Gonzales M; Shuey C; Barney Y; Lewis J Elevated arsenic and uranium concentrations in unregulated water sources on the Navajo Nation, USA. Expos. Health 2017, 9 (2), 113-124.

(13). Smedley PL; Kinniburgh DG A review of the source, behaviour and distribution of arsenic in natural waters. Appl. Geochem 2002, 17 (5), 517-568. 
(14). Burns PC $\mathrm{U}^{6+}$ minerals and inorganic compounds: insights into an expanded structural hierarchy of crystal structures. Can. Mineral 2005, 43 (6), 1839-1894.

(15). Burns PC; Ewing RC; Hawthorne FC The crystal chemistry of hexavalent uranium; polyhedron geometries, bond-valence parameters, and polymerization of polyhedra. Can. Mineral 1997, 35 (6), 1551-1570.

(16). Krivovichev SV; Plášil J; Burns P; Sigmon G In Mineralogy and crystallography of uranium, Uranium: From Cradle to Grave. Mineralogical Association of Canada Short Courses, 2013; pp $15-119$.

(17). Creamer NJ; Baxter-Plant VS; Henderson J; Potter M; Macaskie LE Palladium and gold removal and recovery from precious metal solutions and electronic scrap leachates by Desulfovibrio desulfuricans. Biotechnol. Lett 2006, 28 (18), 1475-1484. [PubMed: 16909331]

(18). Dong W; Brooks SC Determination of the Formation Constants of Ternary Complexes of Uranyl and Carbonate with Alkaline Earth Metals $\left(\mathrm{Mg}^{2+}, \mathrm{Ca}^{2+}, \mathrm{Sr}^{2+}\right.$, and $\left.\mathrm{Ba}^{2+}\right)$ Using Anion Exchange Method. Environ. Sci. Technol 2006, 40 (15), 4689-4695. [PubMed: 16913125]

(19). Dong W; Brooks SC Formation of aqueous $\mathrm{MgUO}_{2}\left(\mathrm{CO}_{3}\right)_{3}{ }^{2-}$ complex and uranium anion exchange mechanism onto an exchange resin. Environ. Sci. Technol 2008, 42 (6), 1979-1983. [PubMed: 18409624]

(20). Stewart BD; Mayes MA; Fendorf S Impact of Uranyl-Calcium-Carbonato Complexes on Uranium(VI) Adsorption to Synthetic and Natural Sediments. Environ. Sci. Technol 2010, 44 (3), 928-934. [PubMed: 20058915]

(21). Othmane G; Allard T; Morin G; Sélo M; Brest J; Llorens I; Chen N; Bargar JR; Fayek M; Calas $\mathrm{G}$ Uranium Association with Iron-Bearing Phases in Mill Tailings from Gunnar, Canada. Environ. Sci. Technol 2013, 47 (22), 12695-12702. [PubMed: 24087982]

(22). Selvakumar R; Ramadoss G; Mridula PM; Rajendran K; Thavamani P; Ravi N; Megharaj M Challenges and complexities in remediation of uranium contaminated soils: A review. J. Environ. Radioact 2018, 192, 592-603. [PubMed: 29525111]

(23). Benjamin MM Water chemistry. Waveland Press, Inc: Long Grove Illinois, USA, 2014.

(24). Dzik EA; Lobeck HL; Zhang L; Burns PC High-temperature calorimetric measurements of thermodynamic properties of uranyl arsenates of the meta-autunite group. Chem. Geol 2018, 493, 353-358.

(25). Knodle R; Agarwal P; Brown M From phosphorous to arsenic: changing the classic paradigm for the structure of biomolecules. Biomolecules 2012, 2 (2), 282-287. [PubMed: 24970138]

(26). He M; Liu X; Cheng J; Lu X; Zhang C; Wang R Uranyl Arsenate Complexes in Aqueous Solution: Insights from First-Principles Molecular Dynamics Simulations. Inorg. Chem 2018, 57 (10), 5801-5809. [PubMed: 29741893]

(27). Daniels WL, The Nature and Properties of Soils, 15th ed.. Soil Sci. Soc. Am. J 2016, 80, (5), 1428.

(28). Bhattacharyya A; Campbell KM; Kelly SD; Roebbert Y; Weyer S; Bernier-Latmani R; Borch T Biogenic non-crystalline $\mathrm{U}((\mathrm{IV}))$ revealed as major component in uranium ore deposits. Nat. Commun 2017, 8, 15538. [PubMed: 28569759]

(29). Finch R; Murakami T Systematics and paragenesis of uranium minerals. Rev. Mineral 1999, 38, 91-180.

(30). Lichtner PC; Hammond GE; Lu C; Karra S; Bisht G; Andre B; Mills RT; Kumar J; Frederick JM PFLOTRAN User Manual. 2019.

(31). Gorman-Lewis D; Burns PC; Fein JB Review of uranyl mineral solubility measurements. J. Chem. Thermodyn 2008, 40 (3), 335-352.

(32). Nipruk OV; Chernorukov NG; Pykhova YP; Godovanova NS; Eremina AA State of uranyl phosphates and arsenates in aqueous solutions. Radiochemistry 2011, 53 (5), 483.

(33). Guillaumont R; Mompean FJ Update on the chemical thermodynamics of uranium, neptunium, plutonium, americium and technetium. Elsevier: Amsterdam, 2003; Vol. 5.

(34). Frondel C Systematic mineralogy of uranium and thorium; 1064; U.S. Geol. Surv: 1958.

(35). Carlson SM; Robinson GW; Elder MJ; Jaszczak JA; Bornhorst TJ Greenockite and Associated Uranium-Vanadium, Minerals from the Huron River Uranium Prospect Baraga County, Michigan. Rocks Miner. 2007, 82 (4), 298-309. 
(36). Roshani M; Mirjalili K Studies on the leaching of an arsenic-uranium ore. Hydrometallurgy 2009, 98 (3-4), 304-307.

(37). Castor SB; Henry CD Geology, geochemistry, and origin of volcanic rock-hosted uranium deposits in northwestern Nevada and southeastern Oregon, USA. Ore Geol. Rev 2000, 16 (1), 140.

(38). Corkhill CL; Crean DE; Bailey DJ; Makepeace C; Stennett MC; Tappero R; Grolimund D; Hyatt NC Multi-scale investigation of uranium attenuation by arsenic at an abandoned uranium mine, South Terras. npj Mater. Degradation 2017, 1 (1), 19.

(39). Mrose ME Studies of Uranium Minerals (XIII). Synthetic Uranospinites. Am. Mineral 1953, 38 (11-1), 1159-1168.

(40). Locock AJ; Burns PC The crystal structure of synthetic autunite, $\mathrm{Ca}\left[\left(\mathrm{UO}_{2}\right)\left(\mathrm{PO}_{4}\right)\right]_{2}\left(\mathrm{H}_{2} \mathrm{O}\right)_{11}$. Am. Mineral 2003, 88 (1), 240-244.

(41). Stojanovicć M; Stevanović D; Milojković J; Mihajlović ML; Lopičić Z; Šoštarić T Influence of Soil Type and Physical-Chemical Properties on Uranium Sorption and Bioavailability. Water, Air, Soil Pollut. 2012, 223 (1), 135-144.

(42). Frost RL; Erickson KL; Weier ML; Carmody O; Cejka J Raman spectroscopic study of the uranyl tricarbonate mineral liebigite. J. Mol. Struct 2005, 737 (2-3), 173-181.

(43). Casas I; Bruno J; Cera E; Finch RJ; Ewing RC Characterization and dissolution behavior of a becquerelite from Shinkolobwe, Zaire. Geochim. Cosmochim. Acta 1997, 61 (18), 3879-3884.

(44). Colmenero F; Fernandez AM; Timon V; Cobos J Becquerelite mineral phase: crystal structure and thermodynamic and mechanical stability by using periodic DFT. RSC Adv. 2018, 8 (43), 24599-24616.

(45). Sandino MCA; Grambow B Solubility equilibria in the U(VI)-Ca-K-Cl- $\mathrm{H}_{2} \mathrm{O}$ system transformation of schoepite into becquerelite and compreignacite. Radiochim. Acta 1994, 66-7, 37-43.

(46). Laurette J; Larue C; Mariet C; Brisset F; Khodja H; Bourguignon J; Carrière M Influence of uranium speciation on its accumulation and translocation in three plant species: Oilseed rape, sunflower and wheat. Environ. Exp. Bot 2012, 77, 96-107.

(47). Tokunaga TK; Kim Y; Wan JM; Yang L Aqueous Uranium(VI) Concentrations Controlled by Calcium Uranyl Vanadate Precipitates. Environ. Sci. Technol 2012, 46 (14), 7471-7477. [PubMed: 22734621]

(48). Gorman-Lewis D; Fein JB; Burns PC; Szymanowski JES; Converse J Solubility measurements of the uranyl oxide hydrate phases metaschoepite, compreignacite, Na-compreignacite, becquerelite, and clarkeite. J. Chem. Thermodyn 2008, 40 (6), 980-990.

(49). Zheng ZP; Tokunaga TK; Wan JM Influence of calcium carbonate on U(VI) sorption to soils. Environ. Sci. Technol 2003, 37 (24), 5603-5608. [PubMed: 14717170]

(50). Dong W; Ball WP; Liu C; Wang Z; Stone AT; Bai J; Zachara JM Influence of Calcite and Dissolved Calcium on Uranium(VI) Sorption to a Hanford Subsurface Sediment. Environ. Sci. Technol 2005, 39 (20), 7949-7955. [PubMed: 16295860]

(51). Clark DL; Hobart DE; Neu MP Actinide Carbonte Complexes and Their Importance in Actinide Environmental Chemistry. Chem. Rev. 1995, 95 (1), 25-48.

(52). Zhou P; Gu B Extraction of Oxidized and Reduced Forms of Uranium from Contaminated Soils: Effects of Carbonate Concentration and pH. Environ. Sci. Technol 2005, 39 (12), 4435-4440. [PubMed: 16047778]

(53). Mason CFV; Turney WRJR; Thomson BM; Lu N; Longmire PA; Chisholm-Brause CJ Carbonate Leaching of Uranium from Contaminated Soils. Environ. Sci. Technol 1997, 31 (10), 2707-2711.

(54). Anawar HM; Akai J; Sakugawa H Mobilization of arsenic from subsurface sediments by effect of bicarbonate ions in groundwater. Chemosphere 2004, 54 (6), 753-762. [PubMed: 14602108]

(55). DeVore CL; Rodriguez-Freire L; Mehdi-Ali A; Ducheneaux C; Artyushkova K; Zhou Z; Latta DE; Lueth VW; Gonzales M; Lewis J; Cerrato JM Effect of bicarbonate and phosphate on arsenic release from mining-impacted sediments in the Cheyenne River watershed, South Dakota, USA. Environ. Sci-Proc. Imp 2019, 21 (21), 456-468. 
(56). Lu G; Forbes TZ; Haes AJ Evaluating Best Practices in Raman Spectral Analysis for Uranium Speciation and Relative Abundance in Aqueous Solutions. Anal. Chem 2016, 88 (1), 773-780. [PubMed: 26607279]

(57). Kelly SD; Kemner KM; Brooks SC; Fredrickson JK; Carroll SL; Kennedy DW; Zachara JM; Plymale AE; Fendorf S Ca-UO $-\mathrm{CO}_{3}$ complexation - Implications for Bioremediation of U(VI). Phys. Scr 2005, T115, 915-917.

(58). Moldovan BJ; Jiang DT; Hendry MJ Mineralogical characterization of arsenic in uranium mine tailings precipitated from iron-rich hydrometallurgical solutions. Environ. Sci. Technol 2003, 37 (5), 873-879. [PubMed: 12666915] 
$\mathrm{O}$ With added bicarbonate at $\mathrm{pH} 3 \Delta$ Without added bicarbonate at pH3 $\quad$ With added bicarbonate at $\mathrm{pH} 7 \Delta$ Without added bicarbonate at $\mathrm{pH} 7$
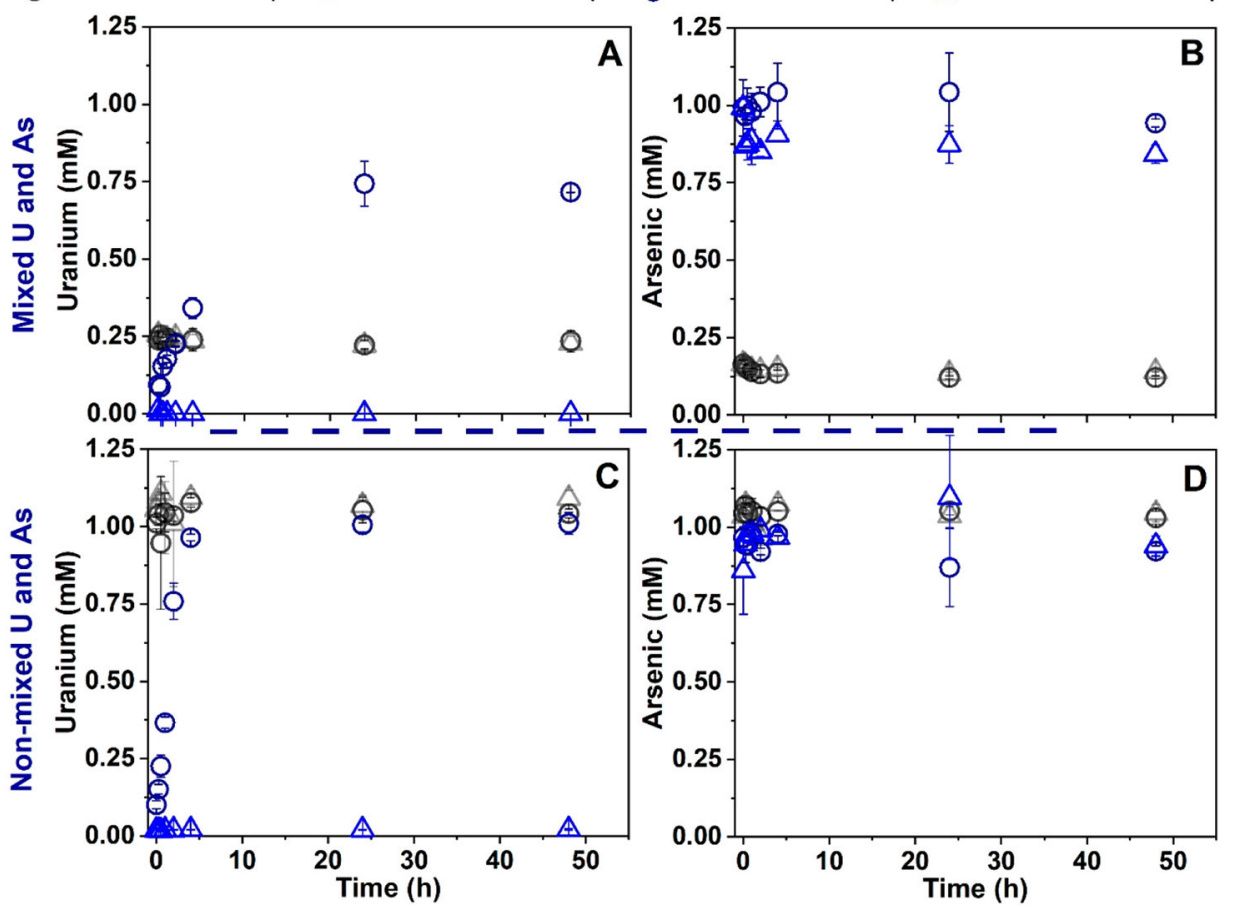

Figure 1.

Aqueous concentration of $U$ and As plotted as a function of time. Assays were initiated with a mixture of $1 \mathrm{mM} \mathrm{U}$ and/or As at $\mathrm{pH} 3$ and $\mathrm{pH} 7$ (A and $\mathrm{B}$ ) and with $1 \mathrm{mM}$ of $\mathrm{U}(\mathrm{C})$ or As (D) at $\mathrm{pH} 3$ and $\mathrm{pH}$ 7. Assays were supplied with $10 \mathrm{mM}$ of calcium $\left(\mathrm{Ca}^{2+}\right)$, with $10 \mathrm{mM}$ of bicarbonate $\left(\mathrm{HCO}^{-}\right)$, and without added bicarbonate $\left(\mathrm{pCO}_{2}=3.5\right)$. Error bars represent the standard deviation of triplicate treatments. 
$\mathrm{O}$ With added bicarbonate at $\mathrm{pH} 3 \Delta$ Without added bicarbonate at $\mathrm{pH} 3$

With added bicarbonate at $\mathrm{pH} 7 \Delta$ without added bicarbonate at $\mathrm{pH} 7$
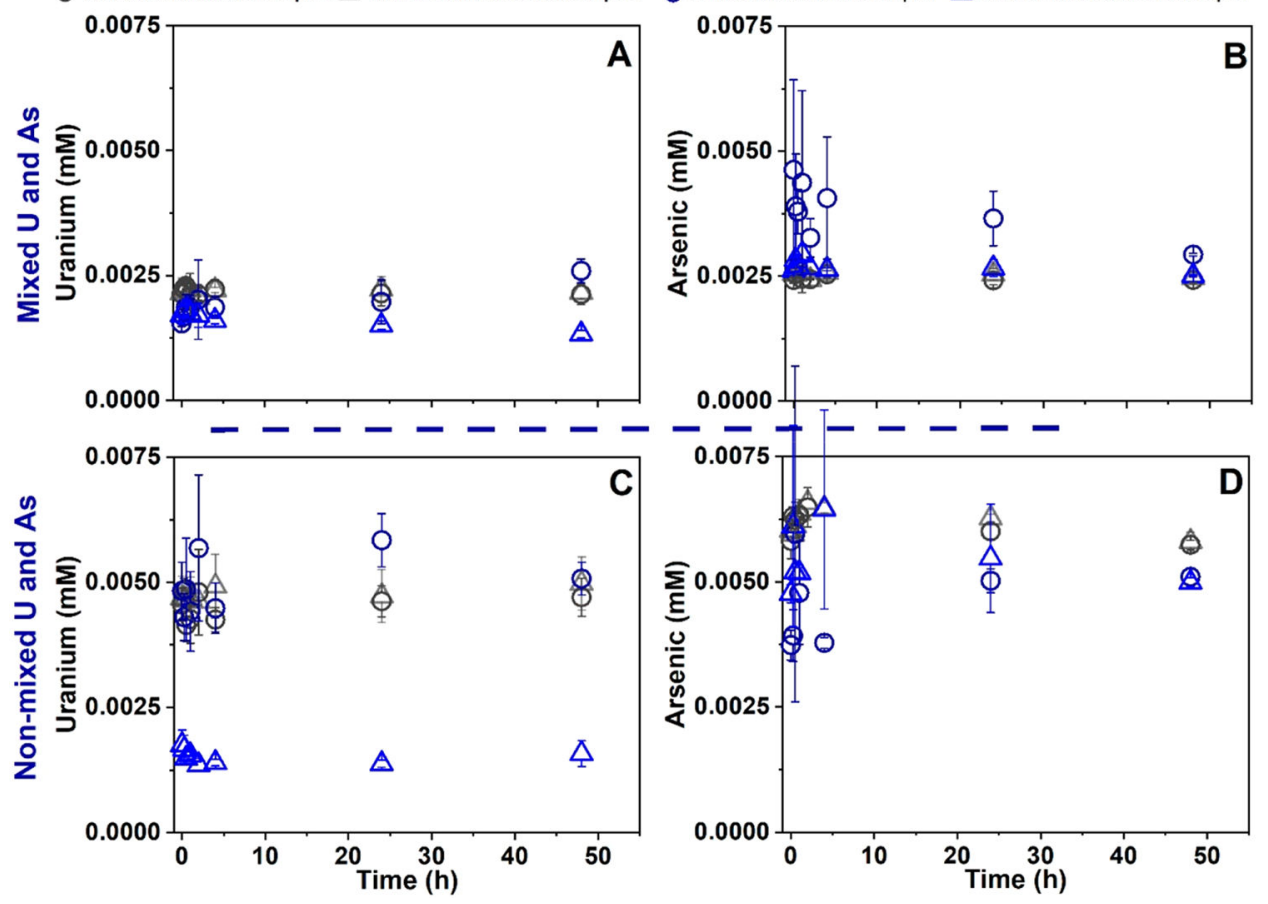

Figure 2.

Aqueous concentration of $U$ and As plotted as a function of time. Assays were initiated with a mixture of $0.005 \mathrm{mM} \mathrm{U}$ and/or As at $\mathrm{pH} 3$ and $\mathrm{pH} 7$ (A and $\mathrm{B}$ ) and with $0.005 \mathrm{mM}$ of $\mathrm{U}$ (C) or As (D) at pH 3 and $\mathrm{pH}$ 7. Assays were supplied with $10 \mathrm{mM}$ calcium $\left(\mathrm{Ca}^{2+}\right)$, with 10 $\mathrm{mM}$ of bicarbonate $\left(\mathrm{HCO}_{3}{ }^{-}\right)$, and without added bicarbonate $\left(\mathrm{pCO}_{2}=3.5\right)$. Error bars represent the standard deviation of triplicate treatments. 

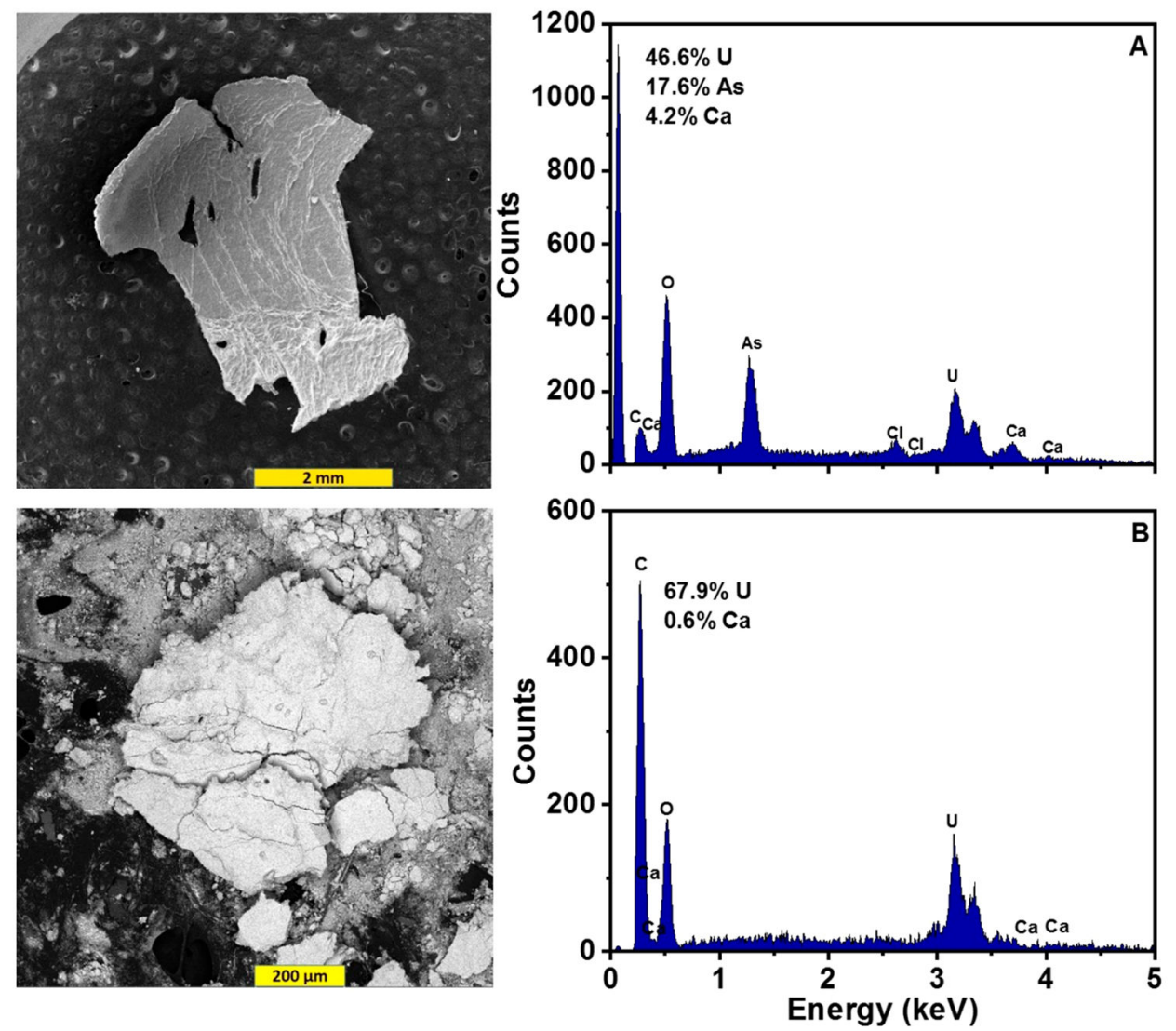

Figure 3.

SEM/EDS analyses of precipitates recovered from experiments initiated with $1 \mathrm{mM} \mathrm{U}$ and As and $10 \mathrm{mM} \mathrm{Ca}$ at $\mathrm{pH} 3$ (A), and $1 \mathrm{mM} \mathrm{U}$ and $10 \mathrm{mM} \mathrm{Ca}$ at $\mathrm{pH} 7$ (B). 

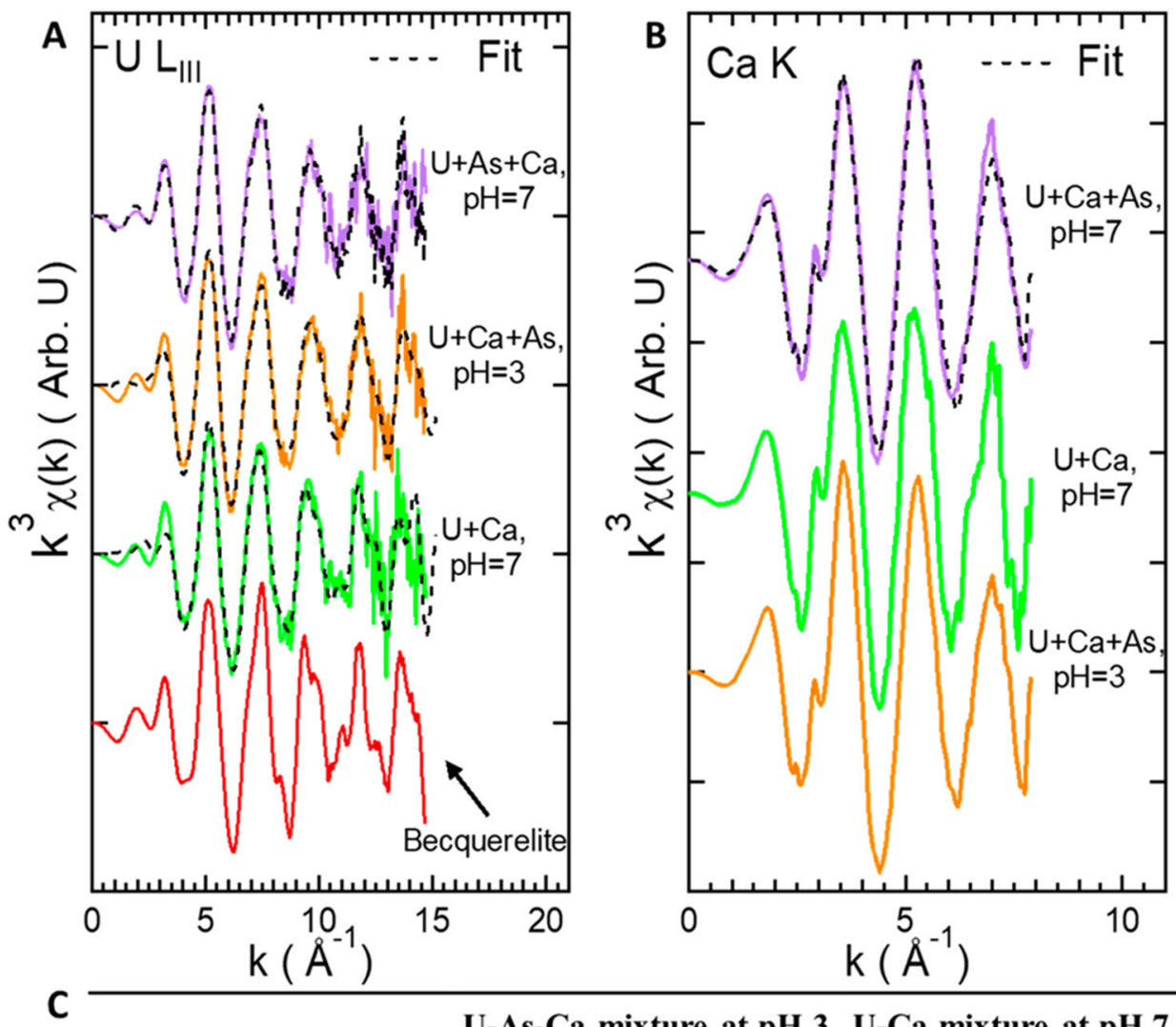

U-As-Ca mixture at pH 3 U-Ca mixture at pH 7

(\%)

$(\%)$

\begin{tabular}{cc}
$\mathrm{UL}_{\text {III }} \mathrm{U}+\mathrm{As}+\mathrm{Ca}, \mathrm{pH} 7$ & $82.0 \%$ \\
$\mathrm{Ca} \mathrm{K} \mathrm{U}+\mathrm{As}+\mathrm{Ca}, \mathrm{pH} 7$ & $71.6 \%$ \\
\hline
\end{tabular}

$18.0 \%$

Figure 4.

EXAFS spectra, shell-by-shell fits, and linear combination fits corresponding to solid samples reacted with $\mathrm{U}$, As, and $\mathrm{Ca}$ at $\mathrm{pH} 3$ and 7: $\mathrm{U} \mathrm{L}_{\mathrm{III}}$-edge EXAFS spectra (A); Ca Kedge EXAFS spectra (B); and results from linear combination fits (C). Solids samples were taken from the experiments supplied with $1 \mathrm{mM}$ of $\mathrm{U}$ and As, $1 \mathrm{mM} \mathrm{U}, 10 \mathrm{mM}$ of $\mathrm{Ca}$ and without added bicarbonate $\left(\mathrm{pCO}_{2}=3.5\right)$. 
Table 1.

Experimental Setup for the Reactivity of Soluble Species ${ }^{a}$

\begin{tabular}{lccccc}
\hline Treatment description & $\mathbf{p H}$ & $\begin{array}{c}\mathbf{A s} \\
(\mathbf{m M})\end{array}$ & $\begin{array}{c}\mathbf{U} \\
(\mathbf{m M})\end{array}$ & $\begin{array}{c}\text { Ca } \\
(\mathbf{m M})\end{array}$ & $\begin{array}{c}\text { Bicarbonate } \\
(\mathbf{m M})\end{array}$ \\
\hline Arsenic, calcium, and bicarbonate & 3 or 7 & 1 & 0 & 10 & 10 \\
Arsenic and calcium without added bicarbonate & 3 or 7 & 1 & 0 & 10 & $\mathrm{pCO}_{2}=3.5$ \\
Uranium, calcium, and carbonate & 3 or 7 & 0 & 1 & 10 & 10 \\
Uranium and calcium without added bicarbonate & 3 or 7 & 0 & 1 & 10 & $\mathrm{pCO}_{2}=3.5$ \\
Uranium, arsenic, calcium, and carbonate & 3 or 7 & 1 & 1 & 10 & 10 \\
Uranium, arsenic, and calcium without added bicarbonate & 3 or 7 & 1 & 1 & 10 & $\mathrm{pCO}_{2}=3.5$ \\
\hline
\end{tabular}

${ }^{a}$ An analogous experiment was performed at $0.005 \mathrm{mM}$ As and/or $\mathrm{U}$. 